\title{
Methyl iodide: Atmospheric budget and use as a tracer of marine convection in global models
}

\section{Citation}

Bell, N., L. Hsu, D. J. Jacob, M. G. Schultz, D. R. Blake, J. H. Butler, D. B. King, J. M. Lobert, and E. Maier-Reimer. 2002. "Methyl lodide: Atmospheric Budget and Use as a Tracer of Marine Convection in Global Models." Journal of Geophysical Research 107, issue D17: 6-1-6-4.

\section{Published Version}

doi:10.1029/2002GL015581

\section{Permanent link}

http://nrs.harvard.edu/urn-3:HUL.InstRepos:14117820

\section{Terms of Use}

This article was downloaded from Harvard University's DASH repository, and is made available under the terms and conditions applicable to Other Posted Material, as set forth at http:// nrs.harvard.edu/urn-3:HUL.InstRepos:dash.current.terms-of-use\#LAA

\section{Share Your Story}

The Harvard community has made this article openly available.

Please share how this access benefits you. Submit a story.

\section{Accessibility}




\title{
Methyl iodide: Atmospheric budget and use as a tracer of marine convection in global models
}

\author{
N. Bell, ${ }^{1,2}$ L. Hsu, ${ }^{1,3}$ D. J. Jacob, ${ }^{1}$ M. G. Schultz, ${ }^{1,4}$ D. R. Blake, ${ }^{5}$ J. H. Butler, ${ }^{6}$ \\ D. B. King, ${ }^{6}$ J. M. Lobert, ${ }^{7}$ and E. Maier-Reimer ${ }^{8}$
}

Received 27 July 2001; revised 28 January 2002; accepted 8 February 2002; published 13 September 2002.

[1] We simulate the oceanic and atmospheric distribution of methyl iodide $\left(\mathrm{CH}_{3} \mathrm{I}\right)$ with a global 3-D model driven by assimilated meteorological observations from the Goddard Earth Observing System of the NASA Data Assimilation Office and coupled to an oceanic mixed layer model. A global compilation of atmospheric and oceanic observations is used to constrain and evaluate the simulation. Seawater $\mathrm{CH}_{3} \mathrm{I}(\mathrm{aq})$ in the model is produced photochemically from dissolved organic carbon, and is removed by reaction with $\mathrm{Cl}^{-}$and emission to the atmosphere. The net oceanic emission to the atmosphere is $214 \mathrm{Gg} \mathrm{yr}^{-1}$. Small terrestrial emissions from rice paddies, wetlands, and biomass burning are also included in the model. The model captures $40 \%$ of the variance in the observed seawater $\mathrm{CH}_{3} \mathrm{I}(\mathrm{aq})$ concentrations. Simulated concentrations at midlatitudes in summer are too high, perhaps because of a missing biological sink of $\mathrm{CH}_{3} \mathrm{I}(\mathrm{aq})$. We define a marine convection index (MCI) as the ratio of upper tropospheric $(8-12 \mathrm{~km})$ to lower tropospheric $(0-2.5 \mathrm{~km}) \mathrm{CH}_{3} \mathrm{I}$ concentrations averaged over coherent oceanic regions. The MCI in the observations ranges from 0.11 over strongly subsiding regions (southeastern subtropical Pacific) to 0.40 over strongly upwelling regions (western equatorial Pacific). The model reproduces the observed MCI with no significant global bias (offset of only $+11 \%$ ) but accounts for only $15 \%$ of its spatial and seasonal variance. The MCI can be used to test marine convection in global models, complementing the use of radon-222 as a test of continental convection. INDEX TERMS: 0312 Atmospheric Composition and Structure: Air/sea constituent fluxes (3339, 4504); 0322 Atmospheric Composition and Structure: Constituent sources and sinks; 0368 Atmospheric Composition and Structure: Troposphere - constituent transport and chemistry; KEYWORDS: methyl iodide, marine convection, atmospheric tracer, global budget of methyl iodide

Citation: Bell, N., L. Hsu, D. J. Jacob, M. G. Schultz, D. R. Blake, J. H. Butler, D. B. King, J. M. Lobert, and E. Maier-Reimer, Methyl iodide: Atmospheric budget and use as a tracer of marine convection in global models, J. Geophys. Res., 107(D17), 4340, doi:10.1029/2001JD001151, 2002.

\section{Introduction}

[2] Methyl iodide $\left(\mathrm{CH}_{3} \mathrm{I}\right)$ is emitted to the atmosphere by the oceans and photolyzes with a lifetime of the order of a week. Aircraft measurements over the past decade have provided large data sets of $\mathrm{CH}_{3} \mathrm{I}$ concentrations over the oceans up to $12 \mathrm{~km}$ altitude [Blake et al., 1999, and

\footnotetext{
${ }^{1}$ Division of Engineering and Applied Sciences, Harvard University, Cambridge, Massachusetts, USA.

${ }^{2}$ Now at NASA/Goddard Institute for Space Studies, New York, New York, USA.

${ }^{3}$ Now at Department of Earth and Planetary Science, University of California, Berkeley, Berkeley, California, USA.

${ }^{4}$ Now at Max Planck Institute für Meteorologie, Hamburg, Germany.

${ }^{5}$ University of California, Irvine, California, USA.

${ }^{6} \mathrm{NOAA} / \mathrm{Climate}$ Monitoring and Diagnostics Laboratory, Boulder, Colorado, USA.

${ }^{7}$ Advanced Pollution Instrumentation, San Diego, California, USA.

${ }^{8}$ Max Planck Institute für Meteorologie, Hamburg, Germany.

Copyright 2002 by the American Geophysical Union. 0148-0227/02/2001JD001151\$09.00
}

references therein]. These observations have been used to constrain vertical mixing rates in 1-D models of atmospheric transport [Davis et al., 1996; Wang et al., 2000, 2002] and to diagnose outflow from marine convection in the upper troposphere [Cohan et al., 1999; Staudt et al., 2002]. Beyond its value as a tracer of transport, $\mathrm{CH}_{3} \mathrm{I}$ is also of interest in the upper troposphere and lower stratosphere as a source of iodine radicals for ozone destruction [Solomon et al., 1994; Davis et al., 1996]. In addition, methyl iodide is a leading candidate to replace methyl bromide as a soil fumigant [Waggoner et al., 2000].

[3] We present here a global 3-D simulation of $\mathrm{CH}_{3} \mathrm{I}$ in the ocean-atmosphere coupled system and use a large ensemble of worldwide atmospheric and oceanic $\mathrm{CH}_{3} \mathrm{I}$ observations to evaluate model results. Our first objective is to develop $\mathrm{CH}_{3} \mathrm{I}$ as a tracer for testing marine convection in global 3-D atmospheric models, complementing the standard use of ${ }^{222} \mathrm{Rn}$ as a tracer for continental convection [Jacob et al., 1997]. Our second objective is to quantify better the global atmospheric budget of $\mathrm{CH}_{3} \mathrm{I}$. 
Table 1. Global $\mathrm{CH}_{3} \mathrm{I}$ Emission Estimates in the Literature

\begin{tabular}{|c|c|c|}
\hline Source & $\begin{array}{c}\text { Global Emission, } \\
\mathrm{Gg} / \mathrm{yr}\end{array}$ & Reference \\
\hline \multirow[t]{7}{*}{ Oceanic $^{\mathrm{a}}$} & 270 & Liss and Slater [1974] \\
\hline & 1300 & Rasmussen et al. [1982] \\
\hline & $300-500$ & Singh et al. [1983] \\
\hline & 140 & Nightingale [1991] \\
\hline & 800 & $\begin{array}{l}\text { Reifenhauser and Heumann } \\
\text { [1992] }\end{array}$ \\
\hline & 150 & Campos et al. [1996] \\
\hline & $130-350$ & Moore and Groszko [1999] \\
\hline \multicolumn{3}{|l|}{ Terrestrial } \\
\hline \multirow[t]{2}{*}{ Biomass burning } & $<10$ & Andreae et al. [1996] \\
\hline & 3.4 & Blake et al. [1996b] \\
\hline \multicolumn{3}{|l|}{ Plant-soil systems } \\
\hline \multirow[t]{2}{*}{ Rice paddies } & 20 & Muramatsu and Yoshida [1995] \\
\hline & 71 & Redeker et al. [2000] \\
\hline Peatland ecosystems & 1.4 & Dimmer et al. [2000] \\
\hline Wetlands & 7.3 & Dimmer et al. [2000] \\
\hline
\end{tabular}

${ }^{a}$ Extrapolated from field measurements over limited regions.

[4] A simple way to implement $\mathrm{CH}_{3} \mathrm{I}$ as a tracer of vertical transport in atmospheric models is to use observed marine boundary layer (MBL) concentrations as a lower boundary condition and simulate the vertical gradient in the tropospheric column. The 1-D models cited above used this approach to constrain their mean vertical transport rates. The approach is less attractive in a time-dependent 3-D model where the MBL concentration should vary in response to the MBL ventilation rate. A boundary condition in the ocean is preferable. We are led therefore to an examination of the oceanic $\mathrm{CH}_{3} \mathrm{I}$ budget.

[5] Data for oceanic concentrations of $\mathrm{CH}_{3} \mathrm{I}$ are available from a number of ship cruises. Extrapolations from individual regional data sets have led to global emission estimates in the literature ranging from 130 to $1300 \mathrm{Gg}$ $\mathrm{yr}^{-1}$ (Table 1). Consideration of the global data base of $\mathrm{CH}_{3} \mathrm{I}(\mathrm{aq})$ concentration measurements allows a more constrained estimate, as described in this paper. Biological sources from algae and phytoplankton have been examined in a number of laboratory studies and could contribute to elevated $\mathrm{CH}_{3} \mathrm{I}$ in coastal environments, but they appear to be negligible on a global scale when compared to the oceanic emission estimates in Table 1 [Manley and Dastoor, 1987, 1988; Nightingale et al., 1995; Manley and de la Cuesta, 1997; Giese et al., 1999]. A laboratory study by Moore and Zafiriou [1994] indicates that photochemical degradation of dissolved organic carbon (DOC) could possibly provide the main oceanic source of $\mathrm{CH}_{3} \mathrm{I}(\mathrm{aq})$. Field measurements by Happell and Wallace [1996] also suggest that the source of $\mathrm{CH}_{3} \mathrm{I}(\mathrm{aq})$ is photochemical. The simulation of $\mathrm{CH}_{3} \mathrm{I}(\mathrm{aq})$ in our global model is more consistent with a photochemical source than with a biological source, as described below.

[6] The main sinks of $\mathrm{CH}_{3} \mathrm{I}(\mathrm{aq})$ in the oceans are thought to be emission to the atmosphere and nucleophilic $\mathrm{S}_{N} 2$ reaction with $\mathrm{Cl}^{-}$. These two sinks are of comparable magnitude [Zafiriou, 1975]; either may dominate depending on surface wind speed (which affects emission to the atmosphere) and seawater temperature (which affects the rate of reaction with $\mathrm{Cl}^{-}$). Hydrolysis is typically an order of magnitude slower than reaction with $\mathrm{Cl}^{-}$[MoelwynHughes, 1938]. Photolysis is unimportant [Zika et al., 1984].
[7] Little is known regarding continental sources of $\mathrm{CH}_{3} \mathrm{I}$ (Table 1). There is a source from rice paddies [Muramatsu and Yoshida, 1995] which Redeker et al. [2000] have estimated to be as large as $71 \mathrm{Gg} \mathrm{yr}^{-1}$ globally. There is a small $\mathrm{CH}_{3} \mathrm{I}$ source from biomass burning of 3-10 $\mathrm{Gg} \mathrm{yr}^{-1}$ [Andreae et al., 1996; Blake et al., 1996b]. Dimmer et al. [2000] have presented evidence for a small source from peatland ecosystems. The continental source of $\mathrm{CH}_{3} \mathrm{I}$ may be much less than the oceanic source on a global scale, but measurements of atmospheric concentrations of $\mathrm{CH}_{3} \mathrm{I}$ over the continents are too few at present to be illuminating.

\section{Model Description}

\subsection{General}

[8] We use the GEOS-CHEM global 3-D model of tropospheric chemistry [Bey et al., 2001a; Liu et al., 2001] driven by assimilated meteorological observations from the Goddard Earth Observing System (GEOS) of the NASA Data Assimilation Office (DAO). Allen et al. [1996a] and Liu et al. [2001] previously used simulations of ${ }^{222} \mathrm{Rn}$ with the GEOS fields to test the representation of continental convection. The GEOS-CHEM model has been applied to a range of tropospheric chemistry problems [Bey et al., 2001a, 2001b; Fiore et al., 2002; Jacob et al., 2002; Li et al., 2000, 2001, 2002; Liu et al., 2001, 2002; Martin et al., 2002a, 2002b; Palmer et al., 2001].

[9] In the present application we use GEOS fields for 1994 available with $2^{\circ}$ latitude $\times 2.5^{\circ}$ longitude horizontal resolution and 20 sigma levels in the vertical extending up to $10 \mathrm{hPa}$. We degrade the horizontal resolution to $4^{\circ} \times 5^{\circ}$ for computational expediency. The lowest $3 \mathrm{~km}$ of the atmosphere are resolved by 6 levels centered at 0.15 , $0.35,0.71,1.2,1.9$, and $2.6 \mathrm{~km}$ above the surface for an air column based at sea level. Advection is computed every 30 min with a flux-form semi-Langrangian method [Lin and Rood, 1996]. Moist convection is computed using the GEOS convective, entrainment, and detrainment mass fluxes as described by Allen et al. [1996a, 1996b]. We assume full vertical mixing within the GEOS-diagnosed atmospheric mixed layer generated by surface instability. The simulation is conducted for 18 months (July 1993 through December 1994) starting from low $\mathrm{CH}_{3} \mathrm{I}$ concentrations as initial conditions. The first 6 months are used to achieve initialization and we focus our attention on the 12month simulation for 1994. Methyl iodide emitted from different sources (ocean, biomass burning, wood fuel, rice paddies, and wetlands), is carried as different tracers in the model.

[10] The atmospheric $\mathrm{CH}_{3} \mathrm{I}$ sink from photolysis is calculated in GEOS-CHEM using the FAST-J algorithm of Wild et al. [2000], implemented as described by Bey et al. [2001a]. Surface albedos and vertically resolved cloud optical depths are taken from the GEOS data with 6-hour resolution. $\mathrm{CH}_{3} \mathrm{I}$ absorbs over the wavelength range $300-$ $340 \mathrm{~nm}$ and we use absorption cross sections from Roehl et al. [1997]. We assume unit quantum yield as has been observed for $\mathrm{CH}_{2} \mathrm{ClI}$ and $\mathrm{CH}_{2} \mathrm{I}_{2}$ in that wavelength range [Roehl et al., 1997, and references therein]. The resulting lifetime of $\mathrm{CH}_{3} \mathrm{I}$ is about 4 days in the tropical troposphere (Figure 1). Oxidation of $\mathrm{CH}_{3} \mathrm{I}$ by $\mathrm{OH}$ is a negligibly small 


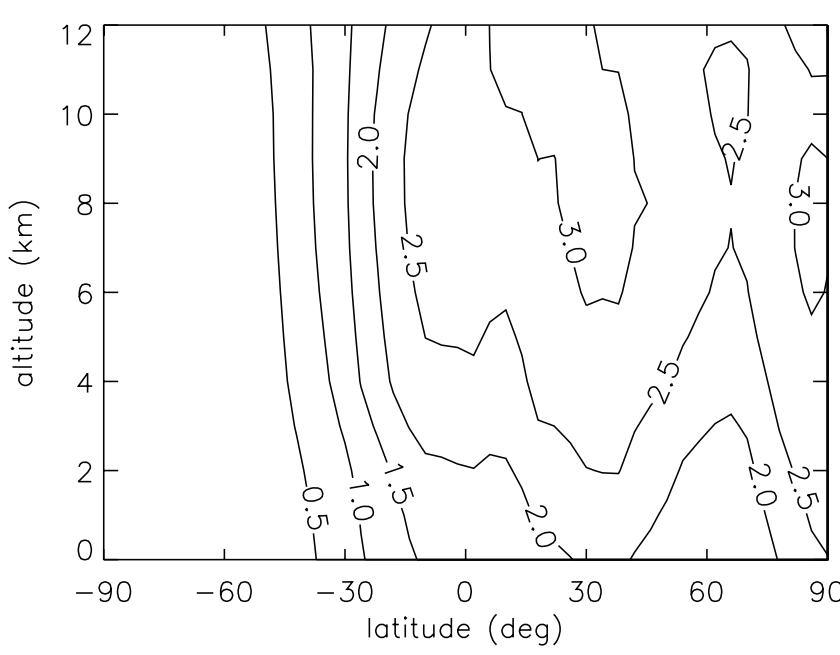

Figure 1. Altitude-latitude plot of the mean 24-hour $\mathrm{CH}_{3} \mathrm{I}$ photolysis frequency $\left(10^{-6} \mathrm{~s}^{-1}\right)$ calculated in the GEOSCHEM model for July 1994.

sink, amounting to only about $1 \%$ of photolysis [Brown et al., 1990].

\subsection{Oceanic Emission of Methyl Iodide}

[11] Oceanic emission of $\mathrm{CH}_{3} \mathrm{I}$ to the atmosphere is computed following Liss and Slater [1974],

$$
\Phi=k\left(\left[\mathrm{CH}_{3} \mathrm{I}(\mathrm{aq})\right]-K_{H}\left[\mathrm{CH}_{3} \mathrm{I}(\mathrm{g})\right]\right) .
$$

Here $\Phi$ is the net flux of $\mathrm{CH}_{3} \mathrm{I}$ from the ocean to the atmosphere representing a balance between emission from the ocean $\left(\Phi_{e m}=k\left[\mathrm{CH}_{3} \mathrm{I}(\mathrm{aq})\right]\right)$ and deposition from the atmosphere $\left(\Phi_{\text {dep }}=-k K_{H}\left[\mathrm{CH}_{3} \mathrm{I}(\mathrm{g})\right]\right)$ and $k$ is the sea-to-air transfer velocity. $K_{H}$ is the dimensionless Henry's law constant for $\mathrm{CH}_{3} \mathrm{I}$ defined as the ratio of aqueous to gasphase concentrations at equilibrium $\left(K_{H}=3.4\right.$ at $298 \mathrm{~K}$ and $1 \mathrm{~atm}, \Delta \mathrm{H}_{298}^{0} / \mathrm{R}=-4300 \mathrm{~K}$ (available at http://www.mpchmainz.mpg.de/sander/res/henry.html)). We parameterize $k$ as a function of the surface wind speed following Nightingale et al. [2000], who found from tracer experiments an optimal wind speed dependence intermediate between the previous results of Liss and Merlivat [1986] and Wanninkhof [1992].

[12] Using a box model for the oceanic mixed layer of depth $z$, and assuming no horizontal flux divergence, we write a steady state expression for the local concentration of $\mathrm{CH}_{3} \mathrm{I}(\mathrm{aq})$,

$$
\left[\mathrm{CH}_{3} \mathrm{I}(\mathrm{aq})\right]=\frac{P+(k / z) K_{H}\left[\mathrm{CH}_{3} \mathrm{I}(\mathrm{g})\right]}{(k / z)+k_{\mathrm{Cl}}\left[\mathrm{Cl}^{-}\right]},
$$

where $P$ is the oceanic production rate per unit volume (ng $\left.\mathrm{L}^{-1} \mathrm{~h}^{-1}\right)$, and $k_{\mathrm{Cl}}$ is the rate constant for reaction with $\mathrm{Cl}^{-}$. We use $k_{\mathrm{Cl}}=7.78 \times 10^{13} \exp [-13518 / \mathrm{T}] \mathrm{M}^{-1} \mathrm{~s}^{-1}$ from Elliott and Rowland [1993], who provide the only temperature-dependent data for this reaction. The temperature dependence is very strong; an increase in ocean mixed layer temperature (MLT) of $20 \mathrm{~K}$ as observed between polar latitudes and the tropics corresponds to an approximately twenty-fold increase in $k_{\mathrm{Cl}}$.
[13] In our simulation we use monthly mean MLT fields from the data set of Woodruff et al. [1987] and a uniform $\left[\mathrm{Cl}^{-}\right]=0.54 \mathrm{M}$. For typical values $k=10 \mathrm{~cm} \mathrm{~h}^{-1}, z=50 \mathrm{~m}$, and $k_{\mathrm{Cl}}=1.2 \times 10^{-3} \mathrm{~h}^{-1}$ (where MLT $=292 \mathrm{~K}$ ), the lifetimes of $\mathrm{CH}_{3} \mathrm{I}(\mathrm{aq})$ against transfer to the atmosphere and reaction with $\mathrm{Cl}^{-}$are 21 and 35 days, respectively, for an overall lifetime of 13 days. Hence ventilation and chemical reaction with $\mathrm{Cl}^{-}$make comparable contributions to the $\mathrm{CH}_{3} \mathrm{I}(\mathrm{aq})$ sink depending on local wind speed and MLT [Zafiriou, 1975].

[14] For our model, we specify the atmospheric concentration $\left[\mathrm{CH}_{3} \mathrm{I}(\mathrm{g})\right]$ in equations (1) and (2) with the local value from the previous time step of the GEOS-CHEM simulation, so that the oceanic and atmospheric simulations are fully coupled. The $\mathrm{CH}_{3} \mathrm{I}(\mathrm{aq})$ production rate $P$ is the effective lower boundary condition of the model. Following the laboratory experiments of Moore and Zafiriou [1994] and the supporting observational evidence of Happell and Wallace [1996], we assume that the production of $\mathrm{CH}_{3} \mathrm{I}(\mathrm{aq})$ in the open oceans is driven by a photochemical mechanism dependent on the supply of dissolved organic carbon (DOC). As a crude parameterization, we scale the production rate as the product of the solar radiation flux at the surface (RAD) and the dissolved organic carbon concentration (DOC),

$$
P=\alpha[\mathrm{RAD} \times \mathrm{DOC}]
$$

where $\alpha$ is a scaling parameter. Monthly average values of RAD are taken from the GEOS fields for 1994, and monthly average fields of DOC are taken from the oceanic GCM of Six and Maier-Reimer [1996]. A value $\alpha=0.1 \mathrm{~m}^{2} \mathrm{~W}^{-1} \mathrm{~h}^{-1}$ was obtained by least-squares fit of model results to observed seawater $\mathrm{CH}_{3} \mathrm{I}(\mathrm{aq})$ concentrations, as described in section 3 . The resulting $\mathrm{r}^{2}$ is 0.4 . A sensitivity simulation where $P$ was scaled to net primary productivity (NPP) to simulate a biological source of $\mathrm{CH}_{3} \mathrm{I}(\mathrm{aq})$ was found to have no success in reproducing the observed distributions of $\mathrm{CH}_{3} \mathrm{I}(\mathrm{aq})$.

[15] The oceanic emission of $\mathrm{CH}_{3} \mathrm{I}$ as computed by the model is thus determined by MLT, RAD, DOC, and wind speed (Figure 2). The model predicts maximum emission at midlatitudes in the spring-summer hemisphere where solar radiation is high and MLT is relatively low. DOC is less variable than RAD in space and time but shows subtropical maxima that contribute to the high $\mathrm{CH}_{3}$ I fluxes there. The annual net emission flux to the atmosphere in the model is $214 \mathrm{Gg} \mathrm{yr}^{-1}$ (Table 2), comparable to the median (270 Gg $\mathrm{yr}^{-1}$ ) of previous estimates (Table 1) but at the low end of

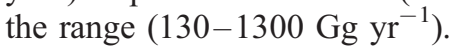

\subsection{Terrestrial Emission of Methyl Iodide}

[16] We include emission of $\mathrm{CH}_{3} \mathrm{I}$ from biomass burning and wood fuel by applying a $\mathrm{CH}_{3} \mathrm{I} / \mathrm{CO}$ emission ratio of 4.0 $\times 10^{-6} \mathrm{vol} / \mathrm{vol}$ [Ferek et al., 1998] to a CO emission inventory with $1^{\circ} \times 1^{\circ}$ spatial resolution and monthly temporal resolution (J.A. Logan, personal communication, 2000). The recent review of Andreae and Merlet [2001] gives $\mathrm{CH}_{3} \mathrm{I} / \mathrm{CO}$ emission ratios of $1.5 \times 10^{-6} \mathrm{vol} / \mathrm{vol}, 1.3 \times$ $10^{-5} \mathrm{vol} / \mathrm{vol}$, and $1.1 \times 10^{-6} \mathrm{vol} / \mathrm{vol}$ for savanna, tropical forest, and extratropical forest, respectively. 

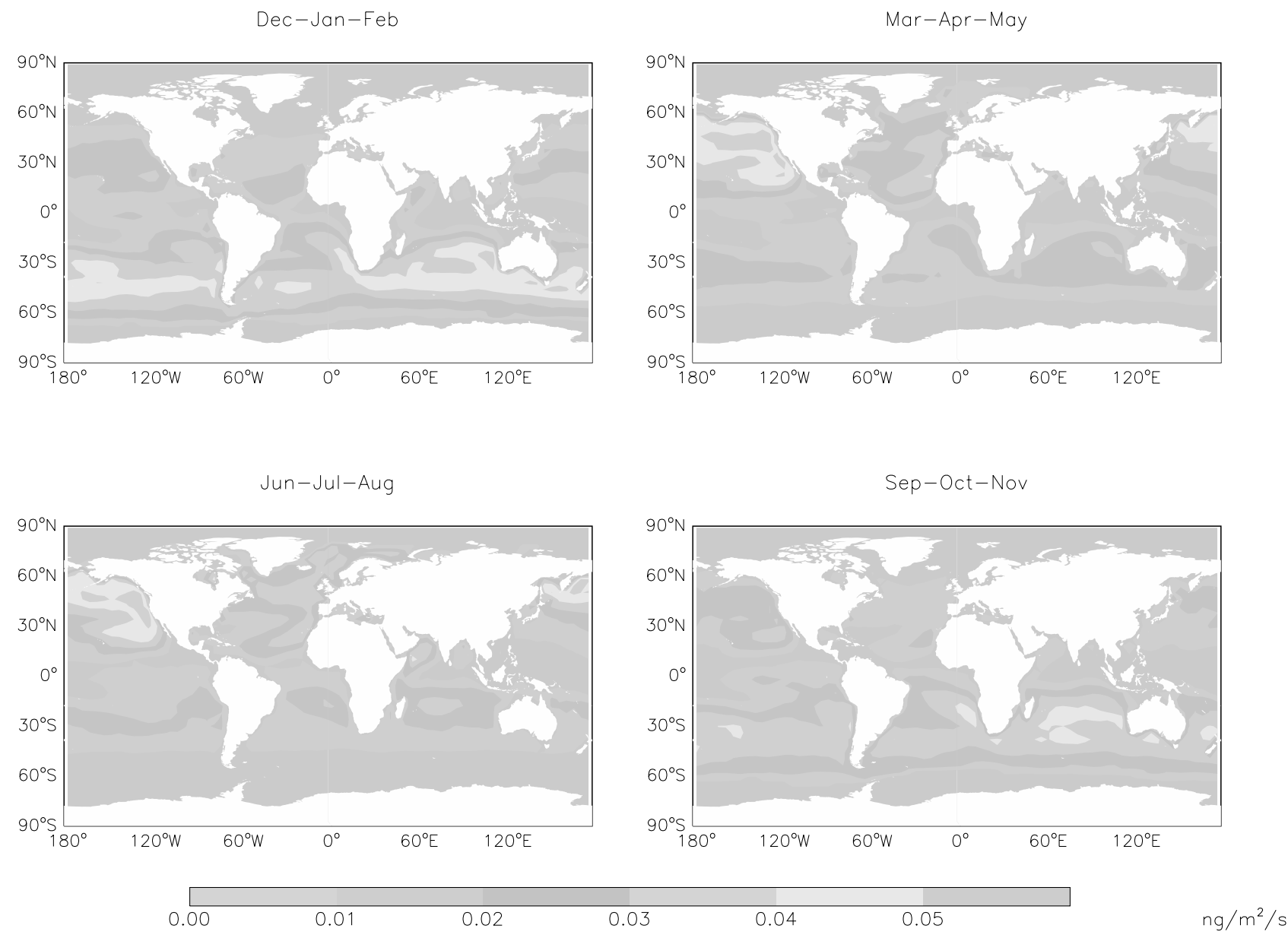

Figure 2. Mean fluxes of $\mathrm{CH}_{3} \mathrm{I}$ from the ocean to the atmosphere for each season computed with the coupled ocean-atmosphere GEOS-CHEM model.

[17] Global $\mathrm{CH}_{3} \mathrm{I}$ emissions from rice paddies and natural

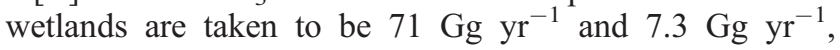
respectively, following the estimates of Redeker et al. [2000] and Dimmer et al. [2000]. These emissions are distributed spatially following the corresponding patterns of $\mathrm{CH}_{4}$ emission from the inventory of Fung et al. [1991]. Peatland ecosystems have been estimated to provide an additional $1.4 \mathrm{Gg} \mathrm{yr}^{-1}$ source of $\mathrm{CH}_{3} \mathrm{I}$ [Dimmer et al., 2000] but this is neglected in the model. Muramatsu and Yoshida [1995] estimated a global source from rice paddies of $20 \mathrm{Gg}$ $\mathrm{yr}^{-1}$, much less than the estimate of Redeker et al. [2000]. As we will see in section 4.1, it appears that the Redeker et al. [2000] estimate may be too high.

[18] Table 3 shows the annual emission flux of $\mathrm{CH}_{3} \mathrm{I}$ to the atmosphere in the model, where each of the five sources

Table 2. Global Oceanic Mixed Layer Budget of $\mathrm{CH}_{3} \mathrm{I}(\mathrm{aq})$ in the Model

\begin{tabular}{lcc}
\hline & Rate, $\mathrm{Gg} \mathrm{yr}^{-1}$ \\
\hline & Sources & \\
Photochemical production & & 16 \\
Atmospheric deposition & Sinks & \\
& & 230 \\
Emission to atmosphere & & 263 \\
Reaction with $\mathrm{Cl}^{-}$ & \\
\hline
\end{tabular}

is represented by a separate tracer. The ocean accounts for $70 \%$ of the global source. Emissions from rice paddies provide a sizeable fraction (24\%) of the global budget of $\mathrm{CH}_{3} \mathrm{I}$ and are highly localized in southeast Asia.

\section{Methyl Iodide Distribution in the Ocean}

[19] Concentrations of $\mathrm{CH}_{3} \mathrm{I}(\mathrm{aq})$ in seawater have been measured on a number of ship cruises. Figure 3 shows these

Table 3. Global Atmospheric Budget of $\mathrm{CH}_{3} \mathrm{I}$ in the Model

\begin{tabular}{|c|c|c|}
\hline & & Values \\
\hline \multicolumn{3}{|c|}{ Sources, $G g y r^{-1}$} \\
\hline Ocean $^{\mathrm{a}}$ & & 214 \\
\hline Rice paddies & & 71 \\
\hline Wetlands & & 7 \\
\hline Biomass burning & & 9 \\
\hline Wood fuel & & 3 \\
\hline Total source & & 304 \\
\hline \multicolumn{3}{|c|}{ Sink, $G g y r^{-1}$} \\
\hline Photolysis & & 304 \\
\hline \multicolumn{3}{|c|}{ Additional Parameters } \\
\hline Inventory, Gg & & 4.8 \\
\hline Lifetime, days & & 6 \\
\hline
\end{tabular}
and atmospheric deposition to the ocean (see Table 2). 

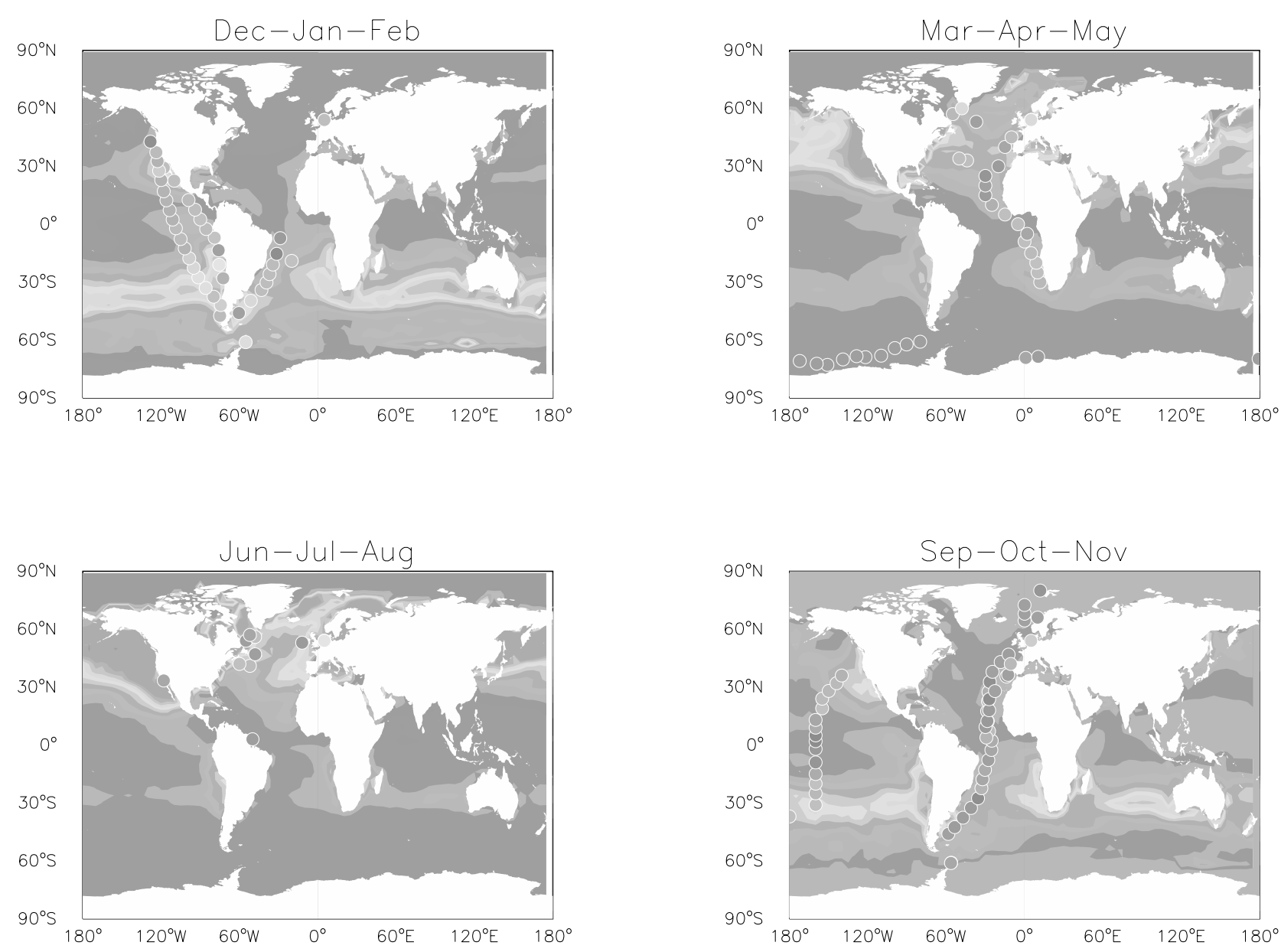

\begin{tabular}{|llllll|}
\hline & & & & & \\
0
\end{tabular}

Figure 3. Global distribution of seawater concentrations of $\mathrm{CH}_{3} \mathrm{I}(\mathrm{aq})$ computed with the GEOS-CHEM model for each season. Observations from ship cruises are superimposed as circles. These observations include data from Lobert et al. [1995] (BLAST 1, January-February 1994, Eastern Pacific), Campos et al. [1996] (January-February 1989, North Sea), Happell and Wallace [1996] (February 1991, South Atlantic), Reifenhauser and Heumann [1992] (December 1987, Antarctica), Schall et al. [1997] (December 1991 to January 1992, Atlantic), and Singh et al. [1983] (December 1991, Eastern Pacific) in DJF; J. Butler (BLAST 3, NOAA/CMDL, unpublished data, 1999) (March-April 1992, Antarctic), Campos et al. [1996] (March-May, 1989, North Sea), Moore and Tokarczyk [1993] (April-May 1991, Greenland/Labrador/Atlantic), Schall et al. [1997] (March 1992, Atlantic), and Tanzer and Heumann [1992] (March-April 1989, Eastern Atlantic) in MAM; Campos et al. [1996] (June-August 1989, North Sea), Happell and Wallace [1996] (June 1993, South Atlantic), Manley and Dastoor [1987] (July 1985, Labrador Sea), and Moore and Groszko [1999] (July 1995, Greenland/Labrador Sea; June 1996, Ireland) in JJA; Lobert et al. [1995] (BLAST 2, October-November 1994, Atlantic), Campos et al. [1996] (September 1989, North Sea), Happell and Wallace [1996] (November 1996, Greenland/Norwegian Sea), Moore and Groszko [1999] (November 1995, Pacific), Reifenhauser and Heumann [1992] (OctoberNovember 1987, Antarctic), Schall and Heumann [1992] (September 1992, Spitzbergen, Fjord), and Schall et al. [1997] (November 1991, Atlantic) in SON.

observations superimposed as circles on the global seawater distribution of $\mathrm{CH}_{3} \mathrm{I}(\mathrm{aq})$ concentrations computed with GEOS-CHEM for each season. Observations from Blast 1 are believed to be artificially high because of a calibration problem and are therefore not included in this data set. There has been no intercalibration between measurements from the different experimental groups. Certain coastal regions appear to be hot spots, for example, the Antarctic
Peninsula [Reifenhauser and Heumann, 1992] and the Peru coast [Singh et al., 1983].

[20] Simulated (monthly mean) and observed $\mathrm{CH}_{3} \mathrm{I}(\mathrm{aq})$ concentrations are correlated with $\mathrm{r}^{2}=0.4$ (Figure 4). The model predicts maximum oceanic concentrations at subtropical to middle latitudes in the summer season where solar radiation is high, but MLT is relatively low. Similar subtropical maxima are seen in some of the cruises [Schall 


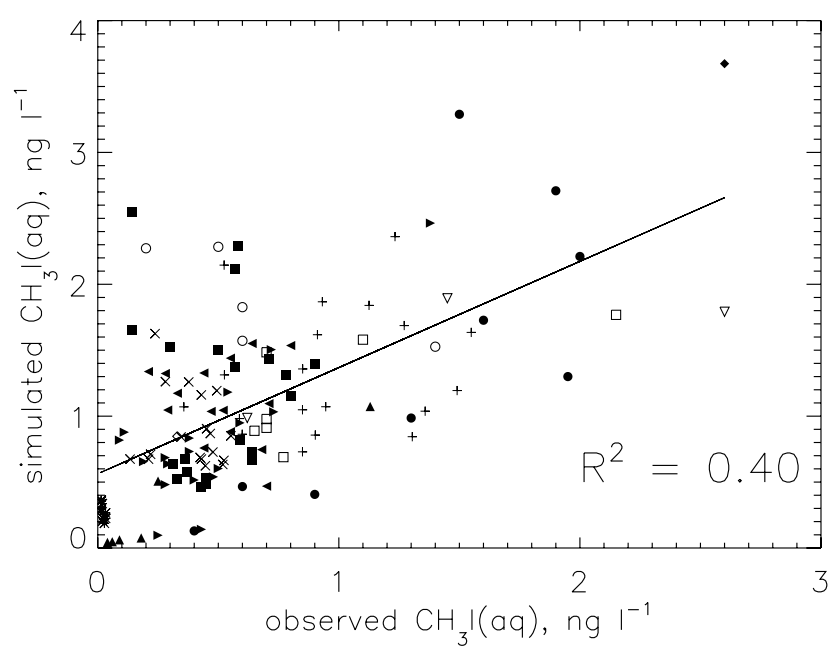

Figure 4. Scatterplot of simulated (monthly mean) versus observed oceanic $\mathrm{CH}_{3} \mathrm{I}(\mathrm{aq})$ concentrations, for the ensemble of observations listed in the legend and shown in Figure 3.

et al., 1997; Moore and Groszko, 1999]. Most of the fine structure in the model distribution is driven by the variability in MLT. Observations are higher in the eastern than in the central Pacific, a feature reproduced by the model and reflecting the gradient in MLT. The relative seasonal amplitude in $\mathrm{CH}_{3} \mathrm{I}(\mathrm{aq})$ concentrations calculated for midlatitudes is about a factor of 6-10. Observations were carried out for 9 months in the North Sea region [Campos et al., 1996], and the results indicate a similar seasonal amplitude and phase.

[21] The model is more successful in the Pacific than the Atlantic. It generally overestimates concentrations in the Atlantic by about a factor of 2 . Most severe is the model overestimate in the Labrador Sea in spring and summer, where simulated concentrations are 1-2 orders of magnitude higher than observations from two separate cruises [Moore and Tokarczyk, 1993; Moore and Groszko, 1999]. Moore and Groszko [1999] noted no correlation with solar radiation in their Labrador Sea data.

[22] More generally, it appears that the model systematically overestimates observations at middle to high latitudes in spring-summer where solar radiation is high and MLT is low. Under these conditions the $\mathrm{CH}_{3} \mathrm{I}(\mathrm{aq})$ loss rate in the model is determined by ventilation to the atmosphere. In order to match observations, one would need an additional loss process with a rate constant of the order of $1 \times 10^{-2}$ $\mathrm{h}^{-1}$. Biological degradation of $\mathrm{CH}_{3} \mathrm{I}$ in seawater or highlatitude upwelling could possibly provide this missing sink but no data are available. A parallel can be drawn to methyl bromide $\left(\mathrm{CH}_{3} \mathrm{Br}\right)$, for which measurements in the open ocean surface waters of the North Atlantic indicate a rate constant for biological degradation that can reach $1.2 \times$ $10^{-2} \mathrm{~h}^{-1}$ [Tokarczyk and Saltzman, 2001]. In high-latitude ocean waters a loss rate of unknown origin of $2.4 \times 10^{-3}$ $\mathrm{h}^{-1}$ was required to explain the observed $\mathrm{CH}_{3} \mathrm{Br}$ subsaturation [Moore and Webb, 1996; Lobert et al., 1997].

[23] The NOAA/CMDL BLAST cruises in the eastern Pacific (BLAST 1), the Atlantic (BLAST 2), and the Antarctic (BLAST 3), provide $\mathrm{CH}_{3} \mathrm{I}$ mixing ratio data for both surface air and seawater [Lobert et al., 1995, 1996; J. Butler, unpublished data, 1999]. These data allow determi- nation of the saturation ratio $S=\Phi_{\text {em }} / \Phi_{\text {dep }}=\left[\mathrm{CH}_{3} \mathrm{I}(\mathrm{aq})\right] /$ $\left(\mathrm{K}_{H}\left[\mathrm{CH}_{3} \mathrm{I}(\mathrm{g})\right]\right)$. The resulting values of $S$ are shown in Figure 5 and compared to the GEOS-CHEM model results. Since the calibration problems associated with the Blast 1 $\mathrm{CH}_{3} \mathrm{I}$ data affect both the air and seawater values, the offset cancels out in the calculation of $S$, and these values are included in Figure 5. Observed saturation ratios are of the order of $50-100$ at $30^{\circ} \mathrm{S}-30^{\circ} \mathrm{N}$ and decrease at higher latitudes. The model captures the magnitude and latitudinal variability in the saturation ratio (Figure 5). In the model, the decrease in $S$ at higher latitudes is driven by larger atmospheric $\mathrm{CH}_{3} \mathrm{I}$ concentrations due to a longer $\mathrm{CH}_{3} \mathrm{I}$ lifetime.

[24] Although $S$ is low for the BLAST 3 cruise carried out at southern latitudes in austral fall, it is greater than unity, indicating that the Southern Ocean is a net source of $\mathrm{CH}_{3}$ I. Previously, Happell and Wallace [1996] measured subsaturation of $\mathrm{CH}_{3} \mathrm{I}$ in the Greenland and Norwegian Seas in November. The model does not find subsaturation in this region, despite close agreement between the model and observed oceanic concentrations of $\mathrm{CH}_{3} \mathrm{I}(0.05 \mathrm{ng} / \mathrm{L})$. The observed atmospheric mixing ratio (2.4 pptv) is much higher than the corresponding model value ( $0.6 \mathrm{pptv})$.

[25] We conducted sensitivity simulations to investigate the possible role of biological production as a source of $\mathrm{CH}_{3} \mathrm{I}(\mathrm{aq})$ to the oceans but results were negative. Scaling the $\mathrm{CH}_{3} \mathrm{I}(\mathrm{aq})$ production rate $P$ to net primary productivity (NPP) fields (taken from Six and Maier-Reimer [1996]) rather than to $\mathrm{DOC} \times \mathrm{RAD}$ in the model resulted in no significant correlation between simulated $\mathrm{CH}_{3} \mathrm{I}(\mathrm{aq})$ fields and the observations of Figure 3. Addition of a biological source scaled to NPP to the photochemical source used in the standard simulation led to a systematic degradation of the comparison between simulated and observed $\mathrm{CH}_{3} \mathrm{I}(\mathrm{aq})$ concentration fields.

\section{Atmospheric Methyl Iodide Distribution}

[26] Our compilation of atmospheric $\mathrm{CH}_{3} \mathrm{I}$ observations comprises six ship cruises and eight aircraft missions (Table

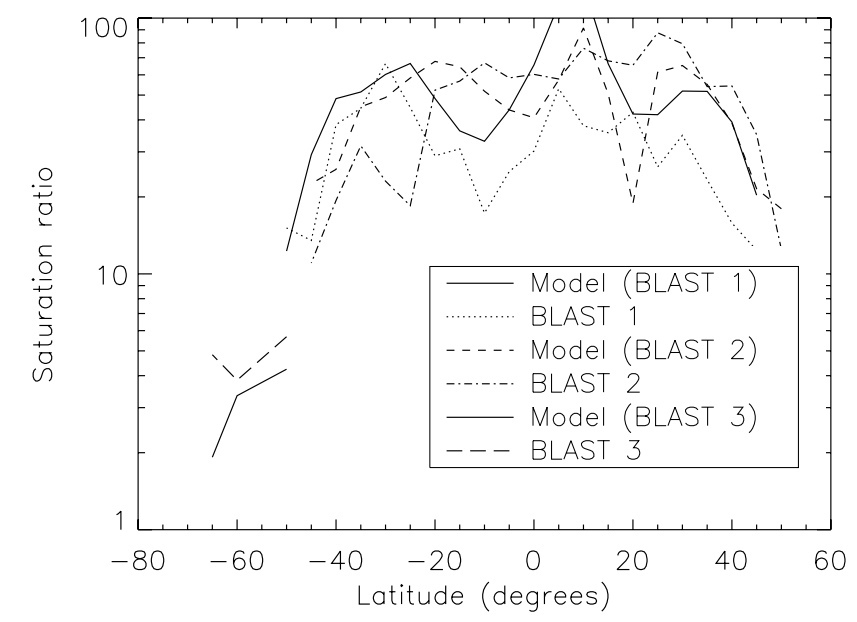

Figure 5. $\mathrm{CH}_{3} \mathrm{I}$ seawater saturation ratio $S=\left[\mathrm{CH}_{3} \mathrm{I}(\mathrm{aq})\right] /$ $\left(\mathrm{K}_{H}\left[\mathrm{CH}_{3} \mathrm{I}(\mathrm{g})\right]\right)$ calculated from the BLAST cruises (Figure 3$)$, as a function of latitude. The corresponding GEOS-CHEM results are shown for comparison. 
Table 4. Atmospheric Methyl Iodide Observations

\begin{tabular}{|c|c|c|}
\hline Observation & Location & Date \\
\hline \multicolumn{3}{|c|}{ Aircraft Missions ${ }^{\mathrm{a}}$} \\
\hline $\operatorname{ACE} 1(6,10,19,20)$ & Australia & 1995 (Nov.-Dec.) \\
\hline $\operatorname{ASTEX}(7)$ & subtropical North Atlantic & 1992 (June) \\
\hline PEM West A $(3,4,5,8,9)$ & northwest Pacific & 1991 (Sept.-Oct.) \\
\hline PEM West B $(3,4,8)$ & northwest Pacific & 1994 (Feb.-March) \\
\hline PEM Tropics A $(6,10,11,12,13,20,21)$ & south tropical Pacific & 1996 (Sept.) \\
\hline PEM Tropics B $(8,10,12,13,21)$ & tropical Pacific & 1999 (March-April) \\
\hline $\operatorname{SONEX}(1,2)$ & North Atlantic & 1997 (Oct. - Nov.) \\
\hline TRACE A $(14,15,16,17,18,22)$ & South Atlantic & 1992 (Aug.) \\
\hline \multicolumn{3}{|c|}{ Ship Cruises } \\
\hline BLAST 1 [Lobert et al., 1995, 1996] & eastern Pacific & 1994 (Jan.-Feb.) \\
\hline BLAST 2 [Lobert et al., 1995, 1996] & Atlantic & 1994 (Nov.) \\
\hline BLAST $3^{\mathrm{b}}$ & Antarctic & 1996 (March) \\
\hline Reifenhauser and Heumann [1992] & Antarctic & 1987 (Dec.) \\
\hline Singh et al. [1983] & eastern Pacific & 1981 (Dec.) \\
\hline Yokouchi et al. [1997] & South China Sea & 1992 (Sept.-Oct.) \\
\hline Yokouchi et al. [1997] & Bay of Bengal & 1994 (Jan.-March) \\
\hline
\end{tabular}

4). Data from the eight aircraft missions were divided into 21 regions (Figure 6) chosen for their relatively homogeneous air mass characteristics and for conformity with the regions previously selected by Emmons et al. [2000] for averaging of aircraft atmospheric chemistry observations. The aircraft data are mostly over the Pacific and are clustered in the September-October and February-March periods. Data from Blast 1 (Pacific Ocean, January-February 1994) are not included because a calibration offset results in an overestimation of the atmospheric mixing ratios.

\subsection{Marine Boundary Layer}

[27] Figure 6 shows the geographical distribution of boundary layer $(0-1 \mathrm{~km})$ concentrations for the two seasons. Comparison of ship with collocated aircraft $(0.2-1$ $\mathrm{km})$ measurements show that the latter are on average $50 \%$ lower. Although the discrepancy might be due to a calibration difference, it could also reflect a vertical gradient of $\mathrm{CH}_{3} \mathrm{I}$ concentrations between the surface layer (sampled by the ships) and the MBL (sampled by aircraft). Such a gradient between the surface layer and the MBL has been previously noted in the case of DMS between concurrent ship and aircraft measurements during the ACE-1 mission [Suhre et al., 1998; Mari et al., 1998]. The discrepancy is inconsequential for the model calculation of the sea-to-air flux of $\mathrm{CH}_{3} \mathrm{I}$ since $S \gg 1$ under almost all conditions.

[28] The right-hand panels of Figure 6 show the distributions of atmospheric $\mathrm{CH}_{3} \mathrm{I}$ in the GEOS-CHEM model. For comparison with the aircraft regions, the model data have been averaged between 0 and $1 \mathrm{~km}$, and for comparison with the ship observations the model data are for the lowest model layer $(0-0.15 \mathrm{~km})$. The model overestimates observed mixing ratios by a factor of 3 over the Southern Ocean and Tasman Sea (regions 19 and 20) during the austral summer, suggesting an overestimated source or a missing seasonal sink, perhaps biological, for $\mathrm{CH}_{3} \mathrm{I}$ in the ocean; such a sink was proposed previously in section 3 from comparison of simulated and observed $\mathrm{CH}_{3} \mathrm{I}(\mathrm{aq})$ concentrations. The high concentrations off the coast of China in the model summer reproduce qualitatively the same feature in the observations but are too high by a factor of 2 . Rice paddies are the dominant source of $\mathrm{CH}_{3} \mathrm{I}$ for this region in the model, and the overestimate suggests that the rice paddy source of $\mathrm{CH}_{3} \mathrm{I}$ from Redeker et al. [2000] is too high.

[29] It is evident from Figure 6 that the model has difficulty reproducing the patterns observed in the $\mathrm{CH}_{3} \mathrm{I}$ MBL concentration field. This problem does not necessarily compromise the use of the relative $\mathrm{CH}_{3} \mathrm{I}$ vertical profiles as a test of convection, as demonstrated in the following section.

\subsection{Vertical Profiles}

[30] Observed vertical profiles of $\mathrm{CH}_{3} \mathrm{I}$ concentrations for selected regions of Figure 6 are compared to model results in Figure 7. In most cases the simulated concentrations are dominated by the oceanic source. When another source contributes more than $5 \%$ to the total sum, it is explicitly indicated. The rice paddy source makes a $30 \%$ contribution to the $\mathrm{CH}_{3} \mathrm{I}$ concentration in the upper troposphere over the North Pacific and Hawaii during PEM-West A and ACE 1. Biomass burning accounts for $50 \%$ of the boundary layer concentration of $\mathrm{CH}_{3} \mathrm{I}$ over Africa (regions 17 and 18) during the Trace-A mission.

[31] Concentrations of $\mathrm{CH}_{3} \mathrm{I}$ in the tropics decrease with altitude up to $2-3 \mathrm{~km}$, representing the base of the trade wind inversion (TWI). Transport to higher altitudes generally involves wet convection. Many of the profiles in Figure 7 show enhanced concentrations in the middle and upper troposphere (UT) associated with deep convection. In most cases the overall vertical gradient in the tropical free troposphere is weak, indicating that convective outflow is distributed over all altitudes [Wang et al., 2000, 2002]. Comparison of the simulated and observed profiles indicates that the model reproduces the gradual decrease with altitude in the lower troposphere (LT), the location of the TWI at $2-3 \mathrm{~km}$ altitude, and the lack of mean vertical gradient at higher altitudes. There is a tendency in the model, and to a somewhat lesser degree in the observations, for a "C-shaped" vertical profile with high concentrations in the UT reflecting preferential deep convection [Prather and Jacob, 1997]. 

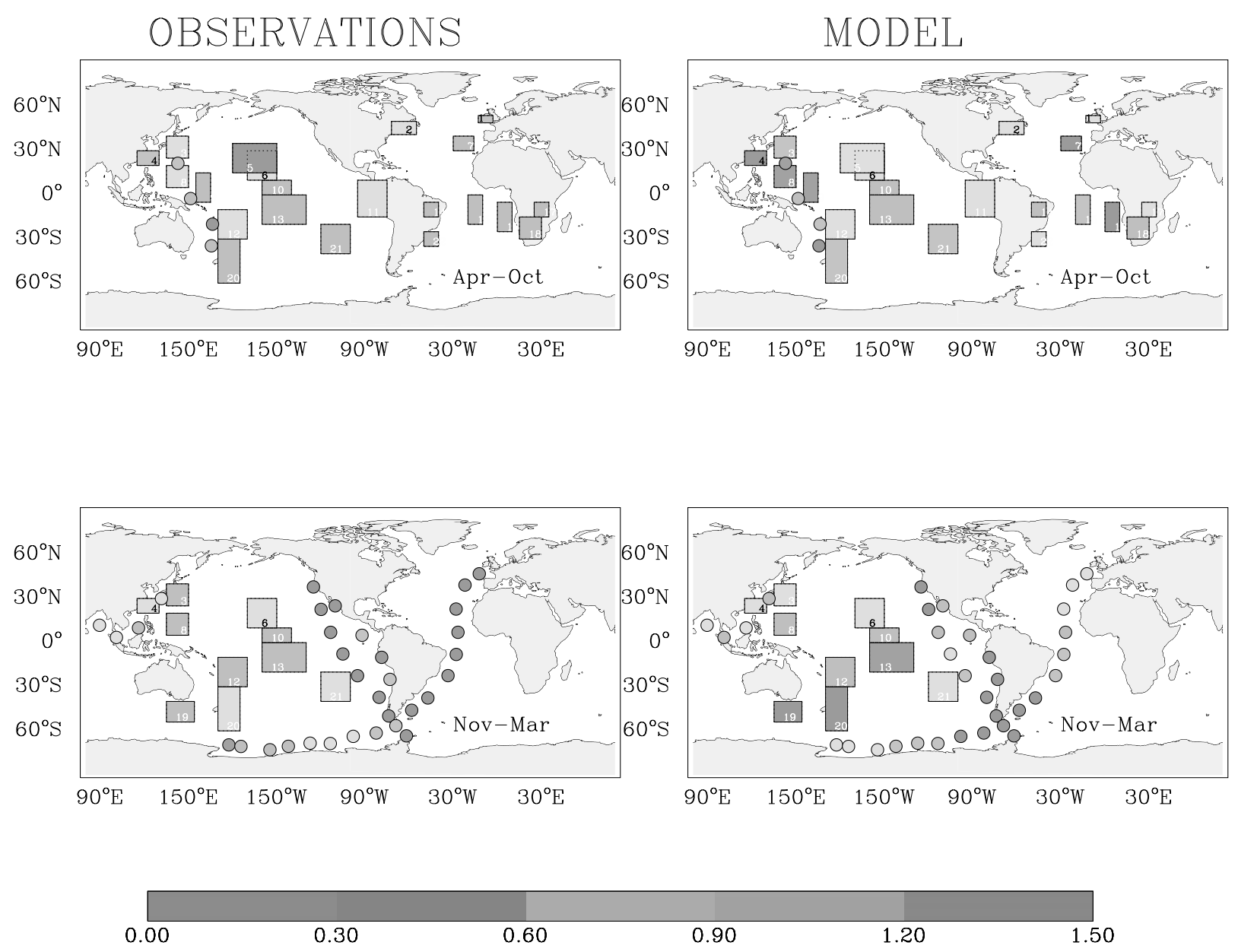

Figure 6. Atmospheric $\mathrm{CH}_{3} \mathrm{I}$ concentrations in the marine boundary layer in (top) April-October and (bottom) November-March. Observations are shown in the left-hand panels, and the model results are shown in the right-hand panels. Circles are ship cruise data. Rectangles are aircraft data at 0- to 1-km altitude averaged over coherent regions [Emmons et al., 2000]. References for the observations are given in Table 4. The model data are averaged between 0 and $1 \mathrm{~km}$ for the aircraft regions, while for the ship regions, the model data from the lowest atmospheric layer $(0-0.15 \mathrm{~km}$ altitude) are shown. The scale has been chosen to highlight the variability between the different regions; the BLAST 1 ship cruise data in the eastern Pacific in January-February (Table 4) are anomalously high and exceed the 1.5 pptv maximum of the scale.

[32] Although errors in the simulation of MBL concentrations (section 4.1) complicate the interpretation of the vertical profiles in Figure 7 it is in fact the shapes of these profiles, rather than the absolute concentrations, that provide a diagnostic of vertical transport. We define therefore a marine convection index (MCI) as the ratio of the mean $\mathrm{CH}_{3} \mathrm{I}$ concentration at 8-12 $\mathrm{km}$ (upper troposphere, UT) to the mean concentration at $0-2.5 \mathrm{~km}$ (lower troposphere, LT) for a given region. The observed and simulated values of the MCI are shown in Table 5 for the Pacific regions of Figure 7. Table 5 also shows the $\mathrm{CH}_{3} \mathrm{I}$ lifetime for each region, which falls in a narrow range (4.0-4.8 days).

[33] The observed MCI values in Table 5 range from 0.11 (Easter Island) to 0.40 (Fiji in March-April), representing large differences in deep convective activity. During PEMTropics B (March-April) the observed MCI is highest over the tropical western Pacific (Fiji) and decreases from west to east, consistent with the large-scale upwelling and subsidence associated with the Walker circulation. During PEM-
Tropics A (September), the MCI is highest over the central South Pacific (Tahiti). The relatively low MCIs observed over Hawaii $(0.20-0.26)$ reflect the general subsidence due to the North Pacific High. All regions in the equatorial and South Pacific indicate higher MCIs (greater convective mixing) during PEM-Tropics B than PEM-Tropics A, consistent with the wet season timing of PEM-Tropics B [Wang et al., 2002]. The strongest seasonal difference is over Fiji where the MCI decreases from 0.4 in March-April (PEMTropics B) to 0.16 in September (PEM-Tropics A). Higher ratios are also found over Hawaii for PEM-Tropics B $(0.26)$ than for PEM-Tropics A $(0.20)$, for reasons that are less clear since the timing of PEM-Tropics B corresponds to the local dry season.

[34] The model reproduces the observed MCI with no significant bias (overall offset of only $+11 \%$ ) for the ensemble of data in Table 5, indicating that the GEOS data provide on average a good simulation of deep marine convective mass fluxes over the Pacific. However, the 

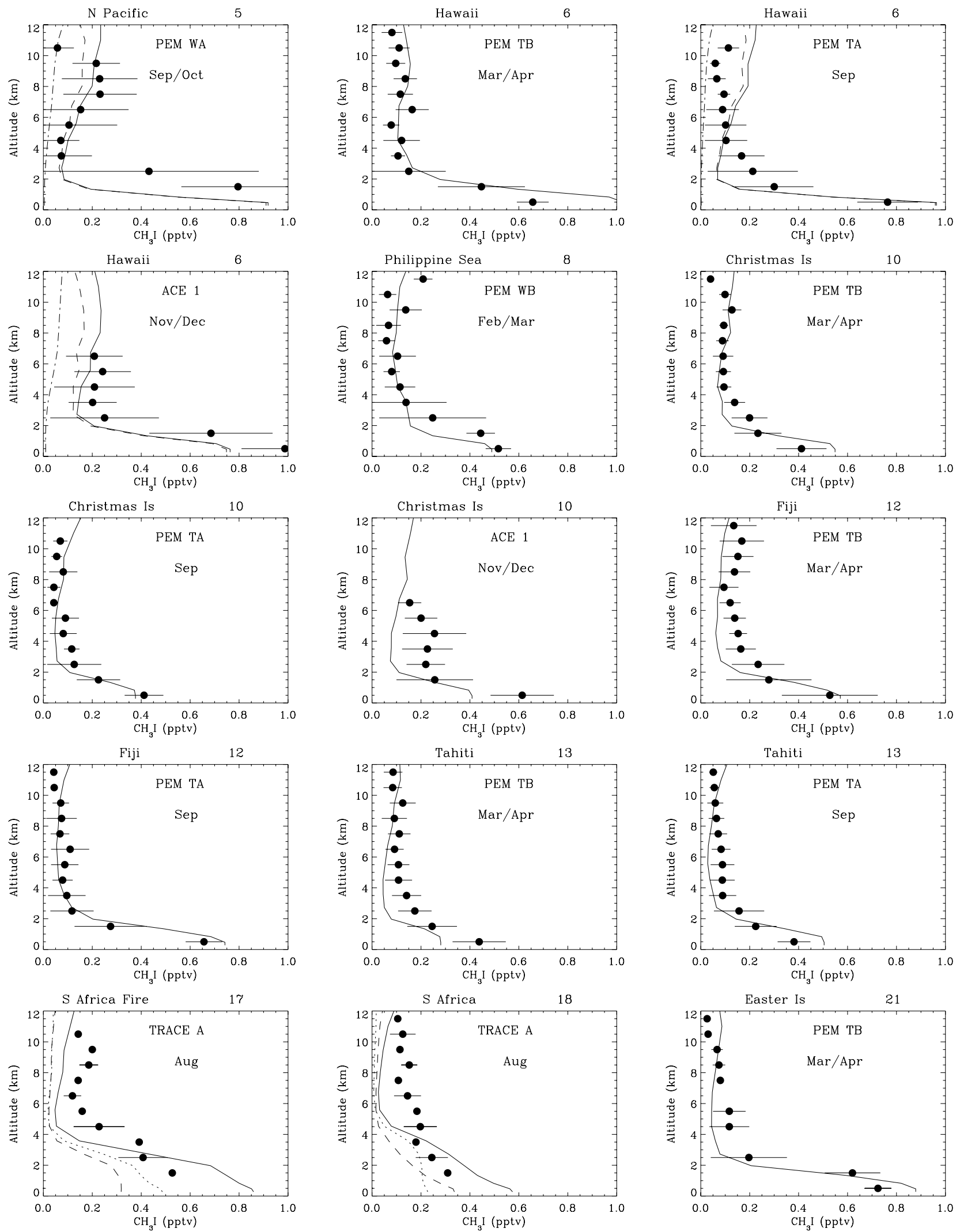

Figure 7. Vertical profiles of $\mathrm{CH}_{3} \mathrm{I}$ concentrations measured from aircraft and averaged over the regions of Figure 6 (region numbers indicated above each plot correspond to those of Figure 6). Horizontal bars are the standard deviations computed from the individual measurements. The corresponding model profiles for the appropriate months are shown as solid black lines. For regions where sources other than oceanic contribute more than $5 \%$ to the total $\mathrm{CH}_{3} \mathrm{I}$ concentrations in the model, the contributions from individual sources are also shown (oceanic (dashed line), biomass burning (dotted line), and rice paddies (dash-dotted line)). 
Table 5. Marine Convection Index (MCI) Over the Pacific: Ratio of Upper Tropospheric (UT; 8-12 km) to Lower Tropospheric (LT; $0-2.5 \mathrm{~km}) \mathrm{CH}_{3}$ I Concentrations

\begin{tabular}{lcccc}
\hline \multicolumn{1}{c}{ Region } & Campaign & $\begin{array}{c}\text { Lifetime, }^{\mathrm{a}} \\
\text { days }\end{array}$ & $\begin{array}{c}\text { MCI } \\
\text { (Observed) }\end{array}$ & $\begin{array}{c}\text { MCI } \\
\text { (Simulated) }\end{array}$ \\
\hline 5. North Pacific & PEM-WA & 4.8 & 0.22 & 0.41 \\
6. Hawaii & PEM-TB & 4.4 & 0.26 & 0.18 \\
8. Philippine Sea & PEM-TA & 4.7 & 0.20 & 0.39 \\
10. Christmas Island & PEM-WB & 4.4 & 0.27 & 0.31 \\
& PEM-TB & 4.0 & 0.32 & 0.30 \\
12. Fiji & PEM-TA & 4.1 & 0.24 & 0.37 \\
13. Tahiti & PEM-TB & 4.3 & 0.40 & 0.22 \\
21. Easter Island & PEM-TA & 4.7 & 0.16 & 0.14 \\
& PEM-TB & 4.2 & 0.34 & 0.44 \\
\hline
\end{tabular}

${ }^{\text {a }}$ Mean model lifetime of $\mathrm{CH}_{3} \mathrm{I}$ in the 0 - to $12-\mathrm{km}$ column (24-hour average).

correlation between simulated and observed values of the MCI is weak $\left(r^{2}=0.15\right)$. The model reproduces qualitatively the spatial gradients and seasonal variations observed over the South Pacific. The model indicates greater deep convection over Hawaii during PEM-Tropics A than during PEM-Tropics B, consistent with the local wet season but contrary to the observations.

\section{Summary}

[35] We used an oceanic mixed layer model coupled to the GEOS-CHEM 3-D atmospheric transport model to provide a first global simulation of oceanic and atmospheric $\mathrm{CH}_{3} \mathrm{I}$. The model was driven by GEOS assimilated meteorological observations from the NASA Data Assimilation Office. Model results were evaluated with an extensive data base of global observations for $\mathrm{CH}_{3} \mathrm{I}$ in the atmosphere and the oceans. We applied the results to understand the factors controlling the global budget of $\mathrm{CH}_{3} \mathrm{I}$ and to examine the usefulness of $\mathrm{CH}_{3} \mathrm{I}$ as a tracer of marine convection in global atmospheric models, complementing the use of ${ }^{222} \mathrm{Rn}$ as a tracer of continental convection.

[36] The concentration of $\mathrm{CH}_{3} \mathrm{I}(\mathrm{aq})$ in the oceanic mixed layer was modeled by assuming steady state between photochemical production (dependent on solar radiation and DOC), chemical reaction with $\mathrm{Cl}^{-}$ions (dependent on temperature), and exchange with the atmosphere (dependent on wind speed and on the local atmospheric concentration of $\left.\mathrm{CH}_{3} \mathrm{I}\right)$. This formulation accounts for $40 \%$ of the variance in the ensemble of seawater observations. The model predicts high concentrations in the spring-summer hemisphere at midlatitudes where solar radiation is high and seawater temperature is relatively low, but corresponding observations in both the ocean and the air show much lower values than the model. The discrepancy may be possibly due to a missing biological sink for $\mathrm{CH}_{3} \mathrm{I}(\mathrm{aq})$. Measurements of the biological degradation of $\mathrm{CH}_{3} \mathrm{I}(\mathrm{aq})$ are needed.

[37] We calculate a gross production of $\mathrm{CH}_{3} \mathrm{I}(\mathrm{aq})$ in the ocean of $477 \mathrm{Gg} \mathrm{yr}^{-1}$ and a net global $\mathrm{CH}_{3} \mathrm{I}$ source from the ocean to the atmosphere of $214 \mathrm{Gg} \mathrm{yr}^{-1}$. The total emission of $\mathrm{CH}_{3} \mathrm{I}$ from all sources in the model is $304 \mathrm{Gg} \mathrm{yr}^{-1}$, including additional contributions from rice paddies $(71 \mathrm{Gg}$ $\left.\mathrm{yr}^{-1}\right)$, wetlands $\left(7 \mathrm{Gg} \mathrm{yr}^{-1}\right)$, biomass burning $\left(9 \mathrm{Gg} \mathrm{yr}^{-1}\right)$, and wood fuel $\left(3 \mathrm{Gg} \mathrm{yr}^{-1}\right)$. Comparison of model results to observations off the coast of China suggests that the estimate of the source from rice paddies [Redeker et al., 2000] is too high.

[38] We used vertical profiles of $\mathrm{CH}_{3} \mathrm{I}$ observed from aircraft to test the model simulation of vertical transport over the oceans. Observations in the tropical marine atmosphere indicate a gradual decrease up to the trade wind inversion (TWI) at $2-3 \mathrm{~km}$, a sharp transition across the TWI, and little vertical gradient through the rest of the troposphere reflecting convective outflow at all altitudes. We find that the GEOS meteorological fields reproduce qualitatively these features. We went on to use the ratio of observed $\mathrm{CH}_{3} \mathrm{I}$ in the upper troposphere $(8-12 \mathrm{~km})$ to the lower troposphere $(0-2.5 \mathrm{~km})$ as a marine convection index (MCI). The observed MCI over the Pacific ranges from 0.11 for strongly subsiding regions (southeastern subtropical Pacific) to 0.40 for strongly upwelling regions (western equatorial Pacific). The GEOS-CHEM model reproduces the observed MCI values over the Pacific with no significant bias (overall offset of only $+11 \%$ ), implying a good mean simulation of marine convection, but the correlation with the observed MCI for individual regions is weak $\left(\mathrm{r}^{2}=\right.$ $0.15)$. The model reproduces qualitatively the spatial gradients and seasonal variations of the MCI observed over the South Pacific, but the seasonal variations are reversed over Christmas Island and Hawaii. We propose that the MCI can provide a useful diagnostic for testing the simulation of marine convection in global atmospheric models.

[39] Acknowledgments. We thank M. Beherenfeld, R. Moore, C. Dimmer, and Y. Yokouchi for contributing their data, R. M. Yantosca for model support, and D. Cohan for useful discussions. This research was supported by the National Science Foundation Atmospheric Chemistry Program, by the NASA Atmospheric Chemistry Modeling and Analysis Program, and by a Harvard College Research Project grant to L. Hsu.

\section{References}

Allen, D. J., R. B. Rood, A. M. Thompson, and R. D. Hudson, Threedimensional Radon-222 calculations using assimiliated data and a convective mixing algorithm, J. Geophys. Res., 101, 6871-6881, 1996a.

Allen, D. J., P. Kasibhatla, A. M. Thompson, R. B. Rood, B. G. Doddridge, K. E. Pickering, R. D. Hudson, and S. J. Lin, Transport induced interannual variability of carbon monoxide using a chemistry and transport model, J. Geophys. Res., 101, 28,655-28,670, 1996 b.

Andreae, M. O., and P. Merlet, Emission of trace gases and aerosols from biomass burning, Global Biogeochem. Cycles, 15, 955-966, 2001.

Andreae, M. O., et al., Methyl halide emissions from savanna fires in southern Africa, J. Geophys. Res., 101, 23,603-23,613, 1996.

Bey, I., D. J. Jacob, R. M. Yantosca, J. A. Logan, B. Field, A. M. Fiore, Q. Li, H. Liu, L. J. Mickley, and M. Schultz, Global modeling of tropospheric chemistry with assimilated meteorology: Model description and evaluation, J. Geophys. Res., 106, 23,073-23,096, 2001a.

Bey, I., D. J. Jacob, J. A. Logan, and R. M. Yantosca, Asian chemical outflow to the Pacific: Origins, pathways, and budgets, J. Geophys. Res., 106, 23,097-23,114, 2001b.

Blake, D. R., T.-Y. Chen, T. W. Smith Jr., C. J.-L. Wang, O. W. Wingenter, N. J. Blake, F. S. Rowland, and E. W. Mayer, Three-dimensional distribution of NMHCs and halocarbons over the northwestern Pacific during the 1991 Pacific Exploratory Mission (PEM-West A), J. Geophys. Res., 101, 1763-1778, 1996a.

Blake, N. J., D. R. Blake, B. C. Sive, T. Y. Chen, F. S. Rowland, J. E. Collins, G. W. Sachse, and B. E. Anderson, Biomass burning emissions and vertical distribution of atmospheric methyl halides and other reduced carbon gases in the South Atlantic region, J. Geophys. Res., 101, 24,151-24,164, $1996 \mathrm{~b}$.

Blake, N. J., D. R. Blake, O. W. Wingenter, B. C. Sive, C. H. Kang, D. C. Thornton, A. R. Bandy, E. Atlas, F. Flocke, J. M. Harris, and F. S. Rowland, Aircraft measurements of the latitudinal, vertical, and seasonal variations of NMHCs, methyl nitrate, methyl halides, and DMS during 
the First Aerosol Characterization Experiment (ACE 1), J. Geophys. Res., 104, 21,803-21,817, 1999

Brown, A. C., C. E. Canosa-Mas, and R. P. Wayne, A kinetic study of the reactions of $\mathrm{OH}$ with $\mathrm{CH}_{3} \mathrm{I}$ and $\mathrm{CF}_{3} \mathrm{I}$, Atmos. Environ., 24, 361-367, 1990.

Campos, M. L. A. M., P. D. Nightingale, and T. D. Jickells, A comparison of methyl iodide emissions from seawater and wet depositional fluxes of iodine over the southern North Sea, Tellus, Ser. B, 48, 106-114, 1996.

Cohan, D. S., M. G. Schultz, D. J. Jacob, B. G. Heikes, and D. R. Blake, Convective injection and photochemical decay of peroxides in the tropical upper troposphere: Methyl iodide as a tracer of marine convection, $J$. Geophys. Res., 104, 5717-5724, 1999.

Davis, D. D., J. Crawford, S. Liu, S. McKeen, A. Bandy, D. Thornton, F. Rowland, and D. Blake, Potential impact of iodine on tropospheric levels of ozone and other critical oxidants, J. Geophys. Res., 101, 2135-2147, 1996.

Dimmer, C. H., P. G. Simmonds, G. Nickless, and M. R. Bassford, Biogenic fluxes of halomethanes from Irish peatland ecosystems, Atmos. Environ., 35, 321-330, 2000

Elliott, S., and F. S. Rowland, Nucleophilic substitution rates and solubilities for methyl halides in seawater, Geophys. Res. Lett., 20, 1043-1046, 1993.

Emmons, L. K., D. A. Hauglustaine, J.-F. Muller, M. A. Carroll, G. P. Brasseur, D. Brunner, J. Stachelin, V. Thouret, and A. Marenco, Data composites of airborne observations of tropospheric ozone and its precursors, J. Geophys. Res., 105, 20,497-20,538, 2000.

Ferek, R. J., J. S. Reid, P. V. Hobbs, D. R. Blake, and C. Louisse, Emission factors of hydrocarbons, halocarbons, trace gases, and particles from biomass burning in Brazil, J. Geophys. Res., 103, 32,107-32,118, 1998. Fiore, A. M., D. J. Jacob, I. Bey, R. M. Yantosca, B. D. Field, and J. G. Wilkinson, Background ozone over the United States in summer: Origin and contribution to pollution episodes, J. Geophys. Res., 107, 4279, 10.1029/2001JD000982, 2002.

Fung, I., J. John, J. Lerner, E. Matthews, M. Prather, L. P. Steele, and P. J. Fraser, Three-dimensional model synthesis of the global methane cycle J. Geophys. Res., 96, 13,033-13,065, 1991.

Giese, R., F. Laturnus, F. C. Adams, and C. Wiencke, Release of volatile iodinated $\mathrm{C} 1-\mathrm{C} 4$ hydrocarbons by marine macroalgae from various climate zones, Environ. Sci. Technol., 33, 2432-2439, 1999.

Happell, J. D., and D. W. R. Wallace, Methyl iodide in the Greenland/ Norwegian Seas and the tropical Atlantic Ocean: Evidence for photochemical production, Geophys. Res. Lett., 23, 2105-2108, 1996.

Jacob, D. J., et al., Evaluation and intercomparison of global atmospheric transport models using Rn-222 and other short-lived tracers, J. Geophys. Res., 102, 5953-5970, 1997.

Jacob, D. J., B. D. Field, E. Jin, I. Bey, Q. Li, J. A. Logan, and R. M Yantosca, Atmospheric budget of acetone, J. Geophys. Res., 107, 4100, 10.1029/2001JD000694, 2002.

Li, Q., D. J. Jacob, I. Bey, R. M. Yantosca, Y. Zhao, Y. Kondo, and J. Notholt, Atmospheric hydrogen cyanide (HCN): Biomass burning source, ocean sink?, Geophys. Res. Lett., 27, 357-360, 2000.

Li, Q., et al., A tropospheric ozone maximum over the Middle East, Geophys. Res. Lett., 28, 3235-3238, 2001

Li, Q., et al., Transatlantic transport of pollution and its effects on surface ozone in Europe and north America, J. Geophys. Res., 107, 4166, 10.1029/2001JD001422, 2002.

Lin, S. J., and R. B. Rood, Multidimensional flux-form semi-Lagrangian transport schemes, Mon. Weather Rev., 124, 2046-2070, 1996.

Liss, P. S., and L. Merlivat, Air-sea gas exchange rates: Introduction and synthesis, in The Role of Air-Sea Exchange in Geochemical Cycling, edited by P. Buat-Menard, pp. 113-129, D. Reidel, Norwell, Mass., 1986.

Liss, P. S., and P. G. Slater, Flux of gas across the air-sea interface, Nature, 247, 181-184, 1974.

Liu, H., D. J. Jacob, I. Bey, and R. M. Yantosca, Constraints from ${ }^{210} \mathrm{~Pb}$ and ${ }^{7} \mathrm{Be}$ on wet deposition and transport in a global three-dimensional chemical tracer model driven by assimilated meteorological fields, J. Geophys. Res., 106, 12,109-12,128, 2001

Liu, H., D. J. Jacob, L. Y. Chan, S. J. Oltmans, I. Bey, R. M. Yantosca, J. M. Harris, B. N. Duncan, and R. V. Martin, Sources of tropospheric ozone along the Asian Pacific Rim: An analysis of ozonesonde observations, $J$ Geophys. Res., 107, 10.1029/2001JD002005, in press, 2002.

Lobert, J. M., J. H. Butler, S. A. Montzka, L. S. Geller, R. C. Myers, and J. W. Elkins, A net sink for atmospheric $\mathrm{CH}_{3} \mathrm{Br}$ in the East Pacific Ocean, Science, 267, 1002-1005, 1995.

Lobert, J., J. Butler, S. Yvon, S. Montzka, R. Myers, A. Clarke, and J Elkins, Blast 94: Bromine Latitudinal Air/Sea Transect, 1994, Report on oceanic measurements of methyl bromide and other compounds, Tech. Memo. ERL CMDL-10, Natl. Oceanic and Atmos. Admin., Environ. Res. Lab., Boulder, Colo., 1996.
Lobert, J. M., S. A. Yvon, J. H. Butler, S. A. Montzka, and R. C. Myers, Undersaturation of $\mathrm{CH}_{3} \mathrm{Br}$ in the Southern Ocean, Geophys. Res. Lett., 24, 171-172, 1997

Manley, S. L., and M. N. Dastoor, Methyl halide $\left(\mathrm{CH}_{3} \mathrm{X}\right)$ production from the giant kelp, Macrocystis, and estimates of global $\mathrm{CH}_{3} \mathrm{X}$ production by kelp, Limnol. Oceanogr., 32, 709-715, 1987.

Manley, S. L., and M. N. Dastoor, Methyl iodide production by kelp and associated microbes, Mar. Biol., 98, 477-482, 1988.

Manley, S. L., and J. L. de la Cuesta, Methyl iodide production from marine phytoplankton cultures, Limnol. Oceanogr., 42, 142-147, 1997.

Mari, C., K. Suhre, T. S. Bates, J. E. Johnson, R. Rosset, A. R. Bandy, F. L. Eisele, R. L. Mauldin III, and D. S. Thornton, Physico-chemical modeling of the First Aerosol Characterization Experiment (ACE 1) Lagrangian B, 2, DMS emission, transport and oxidation at the mesoscale, J. Geophys. Res., 103, 16,457-16,473, 1998.

Martin, R. V., et al., An improved retrieval of tropospheric nitrogen dioxide from GOME, J. Geophys. Res., 107, 10.1029/2001JD001027, in press, 2002a.

Martin, R. V., et al., Interpretation of TOMS observations of tropical tropospheric ozone with a global model and in situ observations, J. Geophys. Res., 107, 10.1029/2001JD001480, in press, 2002b.

Moelwyn-Hughes, E. A., The hydrolysis of the methyl halides, Proc. R. Soc. London, 164, 295-306, 1938

Moore, R. M., and W. Groszko, Methyl iodide distribution in the ocean and fluxes to the atmosphere, J. Geophys. Res., 104, 11,163-11,171, 1999.

Moore, R. M., and R. Tokarczyk, Volatile biogenic halocarbons in the northwest Atlantic, Global Biogeochem. Cycles, 7, 195-210, 1993.

Moore, R. M., and M. Webb, The relationship between methyl bromide and chlorophyll $a$ in high-latitude ocean waters, Geophys. Res. Lett., 23, 2951-2954, 1996.

Moore, R., and O. Zafiriou, Photochemical production of methyl iodide in seawater, J. Geophys. Res., 99, 16,415-16,420, 1994.

Muramatsu, Y., and S. Yoshida, Volatilization of $\mathrm{CH}_{3} \mathrm{I}$ from the soil-plant system, Atmos. Environ., 29, 21-25, 1995.

Nightingale, P. D., Low molecular weight halocarbons in seawater, Ph.D. thesis, Univ. of East Anglia, Norwich, England, 1991.

Nightingale, P. D., G. Malin, and P. S. Liss, Production of chloroform and other low-molecular-weight halocarbons by some species of macroalgae, Limnol. Oceanogr. 40, 680-689, 1995.

Nightingale, P. D., G. Malin, C. S. Law, A. J. Watson, P. S. Liss, M. I. Liddicoat, J. Boutin, and R. C. Upstill-Goddard, In situ evaluation of airsea gas exchange parameterizations using novel conservative and volatile tracers, Global Biogeochem. Cycles, 14, 373-387, 2000.

Palmer, P. I., D. J. Jacob, K. Chance, R. V. Martin, R. J. D. Spurr, T. P. Kurosu, I. Bey, R. Yantosca, A. Fiore, and Q. Li, Air mass factor formulation for spectrosopic measurements from satellites: Application to formaldehyde and retrievals from GOME, J. Geophys. Res., 106 , $14,539-14,550,2001$.

Prather, M. J., and D. J. Jacob, A persistent imbalance in $\mathrm{HO}_{x}$ and $\mathrm{NO}_{x}$ photochemistry of the upper troposphere driven by a deep tropical convection, Geophys. Res. Lett., 24, 3189-3192, 1997.

Rasmussen, R. A., M. A. K. Khalil, R. Gunawardena, and S. D. Hoyt, Atmospheric methyl iodide, J. Geophys. Res., 87, 3086-3090, 1982.

Redeker, K. R., N.-Y. Wang, J. Low, A. McMillan, S. C. Tyler, and R. Cicerone, Emissions of methyl halides from a CA rice field, Science, 290, 966-968, 2000

Reifenhauser, W., and K. G. Heumann, Determinations of methyl iodide in the Antarctic atmosphere and the South Polar Sea, Atmos. Environ., Part A, 26, 2905-2912, 1992

Roehl, C. M., J. B. Burkholder, G. K. Moortgat, A. R. Ravishankara, and P. J. Crutzen, Temperature dependence of UV absorption cross sections and atmospheric implications of several alkyl iodides, J. Geophys. Res., 102, $12,819-12,829,1997$

Schall, C., and K. G. Heumann, GC determination of volatile organoiodine and organobromine compounds in arctic seawater and air samples, Fresenius J Anal. Chem., 346, 717-722, 1992.

Schall, C., K. G. Heumann, and G. O. Kirst, Biogenic volatile organoiodine and organobromine hydrocarbons in the Atlantic Ocean from $42 \mathrm{~N}$ to $72 \mathrm{~S}$, Fresenius J Anal Chem, 359, 298-305, 1997.

Singh, H. G., L. J. Salas, and R. E. Stiles, Methyl halides in and over the eastern Pacific, J. Geophys. Res., 88, 3684-3690, 1983.

Six, K. D., and E. Maier-Reimer, Effects of plankton dynamics on seasonal carbon fluxes in an ocean general circulation model, Global Biogeochem. Cycles, 10, 559-583, 1996

Solomon, S., R. R. Garcia, and A. R. Ravishankara, On the role of iodine in ozone depletion, J. Geophys. Res., 99, 20,491-20,520, 1994.

Staudt, A. C., D. J. Jacob, J. A. Logan, D. Bachiochi, T. N. Krishnamurti, and N. I. Poisson, Global chemical model analysis of biomass burning and lightning influences over the South Pacific in austral spring, J. Geophys. Res., 107, 4200, 10.1029/2000JD000296, 2002. 
Suhre, K., et al., Physico-chemical modeling of the First Aerosol Characterization Experiment (ACE 1) Lagrangian B, 1, A moving column approach, J. Geophys. Res., 103, 16,433-16,455, 1998.

Tanzer, D., and K. G. Heumann, Gas chromatographic trace-level determination of volatile organic sulfides and selenides and of methyl iodide in Atlantic surface water, Int. J. Environ. Anal. Chem., 48, 17-31, 1992.

Tokarczyk, R., and E. S. Saltzman, Methyl bromide loss rates in surface waters of the North Atlantic Ocean, Caribbean Sea, and eastern Pacific Ocean $\left(8^{\circ} \mathrm{N}-45^{\circ} \mathrm{N}\right)$, J. Geophys. Res., 106, 9843-9851, 2001.

Waggoner, M., H. D. Ohr, C. Adams, J. J. Sims, and D. Gonzalez, Methyl iodide: An alternative to methyl bromide for insectary fumigation, $J$. Appl. Entomol., 124, 113-117, 2000.

Wang, Y. H., S. C. Liu, H. Yu, S. T. Sandholm, T. Y. Chen, and D. R. Blake, Influence of convection and biomass burning outflow on tropospheric chemistry over the tropical Pacific, J. Geophys. Res., 105, 9321-9333, 2000.

Wang, Y. H., et al., Factors controlling tropospheric $\mathrm{O}_{3}, \mathrm{OH}, \mathrm{NO}_{x}$, and $\mathrm{SO}_{2}$ over the tropical Pacific during PEM-Tropics B, J. Geophys. Res., 107, 10.1029/2001JD900084, in press, 2002.

Wanninkhof, R., Relationship between wind speed and gas exchange over the ocean, J. Geophys. Res., 97, 7373-7382, 1992.

Wild, O., X. Zhu, and M. J. Prather, Fast-J: Accurate simulation of in- and below-cloud photolysis in global chemical models, J. Atmos. Chem., 37, 245-282, 2000

Woodruff, S. D., R. J. Slutz, R. L. Jenne, and P. M. Steurer, A comprehensive ocean-atmosphere dataset, Bull. Am. Meteorol. Soc., 68, 1239-1250, 1987.

Yokouchi, Y., H. Mukai, H. Tamamoto, A. Otsuki, C. Saitoh, and Y. Nojiri, Distribution of methyl iodide, ethyl iodide, bromoform, and dibromo- methane over the ocean east and southeast Asian seas and the western Pacific, J. Geophys. Res., 102, 8805-8809, 1997.

Zafiriou, O. C., Reaction of methyl halides with seawater and marine aerosols, J. Mar. Res., 33, 75-81, 1975.

Zika, R. G., L. T. Gidel, and D. D. Davis, A comparison of photolysis and substitution decomposition rates of methyl iodide in the ocean, Geophys. Res. Lett., 11, 353-356, 1984.

N. Bell, NASA/Goddard Institute for Space Studies, 2880 Broadway, New York, NY 10025, USA. (nbell@giss.nasa.gov)

D. R. Blake, Department of Chemistry, University of California, Irvine, 516 Rowland Hall, Irvine, CA 92697, USA. (drblake@uci.edu)

J. H. Butler and D. B. King, NOAA/Climate Modeling and Diagnostics Laboratory, 325 Broadway, Boulder, CO 80303, USA. (J.H.Butler@noaa. gov; Daniel.B.King@noaa.gov)

L. Hsu, Department of Earth and Planetary Science, University of California, Berkeley, McCone Hall, Berkeley, CA 94720, USA. (Lhsu@eps.berkeley.edu)

D. J. Jacob, Division of Engineering and Applied Sciences, Harvard University, Pierce Hall, 29 Oxford Road, Cambridge, MA 02138, USA. (djj@io.harvard.edu)

J. M. Lobert, Advanced Pollution Instrumentation, 6565 Nancy Ridge Drive, San Diego, CA 92121, USA. (jlobert@advpol.com)

E. Maier-Reimer and M. G. Schultz, Max-Planck Institute für Meteorologie, Bundesstrasses 55, D-20146, Hamburg, Germany. (maier-reimer@ kdrz.de; martin.schultz@dkrz.de) 